\title{
Multilingual examinations: towards a schema of politicization of language in end of high school examinations in sub-Saharan Africa
}

\author{
Bassey E. Antia
}

\begin{abstract}
In many countries of sub-Saharan Africa, the release of each year's results for the end of high school examinations heralds an annual ritual of public commentary on the poor state of national education systems. However, the exoglossic/monolingual language regime for these examinations is infrequently acknowledged as contributing to the dismal performance of students. Even less attended to is the manner in which the language of examinations, through shaping students' performances, may be exacerbating social inequalities. This article politicizes the language of examinations in the region in the hope of generating policy and research interest in what is arguably an insidious source of inequality. The article makes three arguments. Firstly, it is argued that current exoglossic/monolingual practices in these examinations constitute a set of sociolinguistic aberrations, with demonstrable negative effects on students' performance. Secondly, it is argued that the gravity of these paradoxical sociolinguistic disarticulations is better appreciated when their social ramifications are viewed in terms of structural violence and social inequality. Thirdly, in considering how to evolve a more socially equitable examination language regime, it is argued that the notion of consequential validity in testing positions translanguaging as a more ecologically valid model of language use in examinations.
\end{abstract}

\section{Introduction}

In many countries across sub-Saharan Africa, the release of each year's results for the major end of high school examinations sees the local media awash with comments of a public incensed by the quality of passes. In 2015, the level of pass that made examinees eligible for university admission in some countries of the region was as follows: 25\% in Senegal (Dia and Mbaye 2015); 17.9\% in Mali (Traoré 2015); 15\% in Eritrea (Ministry of Information 2015); 36.4\% in South Africa (Equal Education 2015); 24.5\% in Botswana (Botswana Examinations Council 2015); 35\% in Nigeria (Nwachukwu 2016); and 31.5\% in Kenya (Daily Nation 2016). The results were of such concern in the respective countries that the press in Senegal (Dia and Mbaye 2015) and Mali (Traoré 2015) described them as disaster - perhaps more appropriately as continuing disaster because results in that year were not substantially worse than in preceding years. In Ghana, there was talk of 'broken hearts' and 'headaches' occasioned by the 2015 school certificate results in which students performed 'abysmally' in the three key subjects of mathematics, English and science (Doozie 2015). In South Africa, part of the concern in 2015 had to do with cohort pass rates, that is, the percentage 
of students (40.7\%) writing the examination and obtaining any class of pass, from the pool that enrolled in the first grade 11 years earlier (Equal Education 2015).

The same themes employed in framing challenges of education in sub-Saharan Africa are frequently drawn upon to explain this pattern of results. It is customary to highlight inadequate teacher supply and quality (Adedeji and Olaniyan 2011), neglect of earlier tiers of education (Fleisch 2008), unavailability of textbooks (Glewwe, Kremmer, and Moulin 2009; Heyneman, Farrell, and Sepulveda-Stuardo 1981), low socio-economic status of students (Bayat, Louw, and Rena 2014), poor infrastructure (Glewwe, Hanushek, Humpage, and Ravina 2011), policy instability, a weak monitoring and evaluation system, and other issues of governance (Kellaghan and Greaney 2003; Glewwe and Kremer 2006). Although the language dimension has been voiced (Ouane and Glanz 2011; Chimbutane 2012; Fakeye 2014; Brock-Utne 2008; Taylor 2014), it would appear concerns articulated are sometimes taken up more as calls for improving the teaching of current official languages of teaching, learning and assessment (Fakeye 2014; Taylor 2014), rather than as a rethink of current examination language policy and practice. As a consequence, a rather insidious source for reproducing social inequality has remained largely unaddressed in the arguably mistaken belief that language proficiency and examination performance are apolitical issues and concerns that fall within the agency of individual students or their teachers.

This article politicizes the language of end of high school examinations in sub-Saharan Africa. It combines theoretical reflections with empirical data to make each of three arguments. Firstly, it is argued that the current monolingual and exoglossic practices in these examinations constitute a set of sociolinguistic aberrations, whose negative effects are borne out by data from analyses of students' scripts and students' performances. Secondly, against the backdrop of the notions of penal accountancy (Foucault 1991) and structural violence (Galtung 1969), it is argued that the gravity of these paradoxical sociolinguistic disarticulations is better appreciated when their social ramifications are viewed in terms of structural violence and inequality. Thirdly, in considering how to evolve a more socially equitable examination language regime, it is argued that the notion of consequential validity positions translanguaging as being potentially a more democratic model of language use in examinations. We draw on secondary data to support the first two arguments while we base the third argument on a combination of primary and secondary data.

\section{Language of examinations versus languages in society: paradoxical sociolinguistic disarticulations}

End of high school examinations in sub-Saharan Africa are administered in languages (English, French, Spanish, Portuguese, Afrikaans) originating in the African experience of various models of European colonialism (indirect rule, assimilation, apartheid). This status quo is the corollary of educational language policies that require the use of, or a transition to, erstwhile colonial languages beyond early schooling (Bamgbose 2000). Considering the multilingual lay of the African land, aptly captured by Fardon and Furniss $(1994,4)$ who describe multilingualism as the African lingua franca, the status quo paints a picture of a set of paradoxical disarticulations. 
Firstly, although Africa (and especially sub-Saharan Africa within which the so-called linguistic fragmentation belt lies) is richly endowed with languages (approximately, 2011 languages, see Bamgbose [2004]), it is paradoxical that only 5 are employed in administering the end of high school examinations. ${ }^{1}$ This is of the 9 reportedly used officially as media of secondary school instruction (UNESCO 2004; Gadelii 2004) and of the estimated 176-212 that feature as medium of instruction (largely in primary education) and as taught subjects in all tiers of formal education and in experimental schooling projects.

Secondly, although within countries of sub-Saharan Africa there are a small number of endoglossic languages of wider communication, used by $70 \%$ or more of national populations (Djité 1990), these languages have paradoxically not yet made it into national examination systems as languages for testing content subjects. Thus, in Eritrea, where the state is committed to the equality of languages,

$75 \%$ of the national population uses just two languages: Tigrinya, which is spoken by $54 \%$ of the population, and Tigre, spoken by 31.4\% (Negash 1999). Yet, the Eritrean School Leaving Certificate Examination is conducted in English, a language whose regular user population is to be found mainly in the small tourist and expatriate communities. In Senegal, although the dominant languages are Wolof, Peul, Serer, Diola, Malinke and Soninke, more than 90\% of Senegalese speak Wolof (Leclerc 2015). Yet, the baccalaureate is administered in French. In Nigeria, although it is estimated that $85 \%$ of the population can be reached through 12 so-called network languages (Antia 1996), none has as yet been used as a medium for testing content subjects in either the nationally or the regionally administered end of high school examinations.

Thirdly, it is paradoxical that the self-same official languages of instruction and of examinations are the ones in which the proficiency of teachers and students is often deplored. In Ethiopia, where in 2010 the fluent speaker base for English was estimated at 0.3\% (Heugh 2011a), English serves as the language for the end of high school examinations. The consequence, according to Johannes (2009, 191), is that English is more appropriately described as a 'medium of obstruction,' rather than of instruction in the experience of both teachers and students. Indeed, across the sub-continent, the observation is that 'many teachers may have a poor command of the language that is the medium of instruction' (Kellaghan and Greaney 2003, 53). In Burkina Faso, Mali, Niger and other countries of West Africa which have French as official language, Alidou and Jung (2002) report that most learners have inadequate knowledge of the French language of instruction.

Fourthly, and significantly for arguments made later on in this article about translanguaging, the heteroglossic practices evident in the broader society in Africa (Banda 2016; Githiora 2016; Mc Laughlin 2009; Fardon and Furniss 1994) are also reflected in all tiers of education (Yevudey 2013; Antia 2017a; Antia and Dyers 2016, 2017), and (specifically of interest to this article) in the manner high school students in the sub-continent learn across African and European languages (Banda 2010; Tabaro 2013; Ferguson 2003). Yet, these students are expected to demonstrate this knowledge in examinations through one, the European, which for many of them is the weaker language. 
Several of these sociolinguistic aberrations are hinged on assumptions that have been contested, for example: aspirations of access to global languages of power being only attainable when European languages are used as media of instruction, rather than simply taught as subjects (cf. Qorro 2009); or an additional language for presenting examination questions only having value if that language had been used as (official) medium of instruction (cf. Antia 2017b). At any rate, the effect which these sociolinguistic disarticulations have on students is easily seen in (secondary) data analysing examination scripts and student performance. In research conducted for the Examinations and Assessment Board of the Gauteng Provincial Department of Education in South Africa, van der Westhuizen et al. (2010) obtained and analysed a random sample of 1000 South African end of high school examination scripts in six subjects. See Textbox 1 for their findings in respect of one subject.

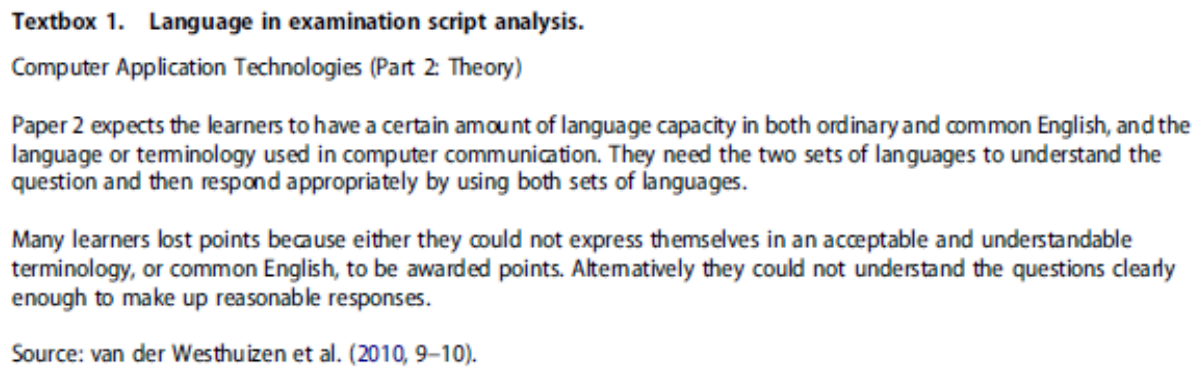

As Textbox 1 shows, success on the particular examination described required receptive as well as productive competencies in English as both general and specialized language. Sadly, many examinees lacked these competencies. Similarly, in its review of the 2015 Uganda Advanced Certificate of Education or A-levels, the examining body noted that candidates 'showed lack of understanding of basic concepts, ... failing to understand key words that define the tasks in the questions' (Uganda National Examinations Board 2016, 5).

It is on the basis of data such as these that a few scholars, swimming against the tide of public and of even some scholarly opinion, have linked the poor performance of students in examinations to language, even while acknowledging other contributors to variance in examination performance. Ouane and Glanz (2011,35-36) argue on the basis of several studies which they review that students' scores in all subjects reflect proficiency levels in the language used in the examination. Their perspective is that of countries in West Africa that have French as official language. From a Mozambican observatory (Mozambique has Portuguese as official language), Chimbutane $(2012,173)$ similarly notes that the high rates of academic failure attested in sub-Saharan Africa are to a large extent linked to the fact that a language foreign to the child' is used. From Nigeria where English is the official language, Fakeye $(2014,39)$ writes that the 'poor performance of Nigerian senior, secondary school students in various school subjects at public examinations has often been blamed on their weakness in English language which is the medium through which knowledge in school subjects is transferred to learners.' Kellaghan and Greaney $(1992,48)$ had observed much earlier that 'in Mauritius [...] where the lingua franca is Creole, some candidates' poor examination performance is due to a failure to understand questions set in English.' They also note, with respect to another country, Madagascar, that the 'low pass rate (38.8 percent) 
recorded by Madagascar students in the Technical Baccalauriat has been attributed to the extensive use of French in the educational system' (Kellaghan and Greaney 1992,48).

Although there is much in the effects of these sociolinguistic disarticulations to warrant policy attention, the lesson that is sometimes drawn, even in insightful analyses, has been the need to strengthen the teaching and learning of current official languages, rather than the reconfiguring of current language arrangements (Fakeye 2014; Taylor 2014). With examination results not infrequently seen as the (exclusive) responsibility of individual students, teachers or schools, the much broader significance of the question of the language of testing is perhaps better appreciated when examinations are placed in the social, political and ideological contexts within which they are produced and their results consumed.

\section{Language of examinations, the social consumption of examination results and the politics of inequality}

Work by Foucault and Galtung easily underpins a social justice approach to language in examinations. Foucault (1991) views penal accountancy as the double system of gratification and punishment through which the examination, functioning as normalizing judgment, exerts social control or disciplinary power. This normalizing gaze of disciplinary power yields 'a punitive penal balance-sheet of each individual' (Foucault 1991, 180), from which emanates 'a differentiation that is not one of acts, but of individuals themselves, of their nature, their potentialities, their level or their value' (Foucault 1991, 181). Examinations make it possible to 'quantify, classify and punish' (Foucault 1991, 184). It follows from this view that the performance of individuals in high stakes examinations potentially brands them for life.

A balance-sheet of academic performance which effectively rewards and punishes on grounds of proficiency in the examination language arguably reinforces the differentiation immanent in other structures of society and the marginality experienced by students who unjustifiably come up short. Sadly, it has been observed that public examinations in Africa tend to 'discriminate against ... students whose first language differs from that of the examination' in addition to minorities, rural populations, and girls (Kellaghan and Greaney 2003, 17). The celebrated Kenyan writer, Ngugi wa Thiong'o, provides a compelling account of this discrimination in the school system in Kenya while he was growing up:

As you may know, the colonial system of education in addition to its apartheid racial demarcation had the structure of a pyramid: a broad primary base, a narrowing secondary middle, and an even narrower university apex. Selections from primary into secondary were through an examination, in my time called Kenya African Preliminary Examination, in which one had to pass six subjects ranging from Maths to Nature Study and Kiswahili. All the papers were written in English. Nobody could pass the exam who failed the English language paper no matter how brilliantly he had done in the other subjects. I remember one boy in my class of 1954 who had distinctions in all subjects except English, which he had failed. He was made to fail the entire exam. He went on to become a turn boy in a bus company. I who had only passes but a credit in English got a place at the Alliance High School, one of the most elitist institutions for Africans in colonial Kenya. (wa Thiong'o 1987, 12) 
Indeed, the potential of such discrimination or differentiation being systemic is elucidated by the notion of structural violence in the work of foremost peace researcher, Johan Galtung. Galtung $(1969,168)$ defines violence as the avoidable difference between 'the potential and the actual, between what could have been and what is,' but also as what impedes the decrease of this difference. The type of violence Galtung describes as structural is said to be embedded in social structure. In a violent structure, experience of the potential - actual gap in one area would tend to be consistent with (and perhaps exacerbate) similar disadvantage immanent in other areas of social structure. In other words, rank dimensions (e.g. low income, poor health, poor educational attainment) correlate. A violent structure shows up 'as unequal power and consequently as unequal life chances' (Galtung 1969, 171). It is said to arise as follows: 'when insight and/or resources are monopolized by a group or a class or are used for other purposes, then the actual level falls below the potential level, and violence is present in the system' (Galtung 1969, 169, my emphasis).

Now, when insight and/or resources around testing in a familiar language or in particular language constellations are monopolized by, or withheld from, a social group or a class, and demonstrably lead to the actual academic achievement level of the deprived group falling below its potential level (as may be determined through alternative linguistic arrangements), then language ineluctably contributes to structural violence. Stated differently, when students who are already socially disadvantaged are, because of language, unable to 'understand the questions clearly enough to make up reasonable responses' (van der Westhuizen et al. 2010, 9-10), then they are at the receiving end of structural violence. To illustrate how issues of social justice may be linked to the language of examinations, let us re-read some secondary datasets related to race, social class and geography.

The results of the end of high school examinations in South Africa (popularly called matric) paint a picture of racial structuring or patterning in students' performance. The pattern in turn appears to racialize access to opportunity, and to exacerbate structural violence in a country with some of the highest levels of inequality on a global scale. Written by approximately $80 \%$ of the yearly cohort (i.e. black South Africans) in the home languages (English and Afrikaans) of less than 20\% of their predominantly white peers, the examinations have consistently seen home users of black South African languages outperformed by home speakers of English and Afrikaans (October 2002; Heugh 2011b; Equal Education 2015). Heugh observes that of 'those who do pass, and who pass well, are those who have mother-tongue education throughout the education system. They are first language speakers of English and Afrikaans' (Heugh 2011b, 261). Taylor (2014) offers a fine-grained analysis of the matric results for 2010 from the standpoint of the performance of white students writing in their home languages (English, Afrikaans) and black African students who often have to write in English, a second or third language for many of them. Taylor finds that where particular groups of students from both demographics have similar levels of performance in a non-language intensive subject (e.g. Accounting) or in non-language intensive aspects of mathematics, significant differences become apparent when it comes to language intensive subjects (History, Geography) or language intensive parts of mathematics: white English-home language students outperform black students. 
Of course, language disadvantage alone does not explain disparities in performance as implied by the correlation of rank dimensions in Galtung's account. Nonetheless, the ramifications of these results are manifold. In 2014, according to the advocacy group, Equal Education, ' $66.7 \%$ of white matrics [end of high school examination candidates] passed well enough to study towards a degree at university' (Equal Education 2015). On the other hand, just 23.8\% of black matrics were eligible for university admission. There is also the question of access to employment in an increasingly knowledge-based economy. According to official South African statistics, in the second quarter of 2015(Q2:2015),

The share of the employed population who are graduates was highest among the white (26.9\%) and Indian/Asian (22.7\%) population groups. ... Relatively small proportions of employed black Africans and the coloured popu- lation group completed tertiary education compared to their white and Indian/Asian counterparts. For one employed black African graduate, there were five employed white graduates and four employed Indian graduates in Q2:2015. (Statistics South Africa 2015, vi)

These statistics need to be seen against the backdrop of the distribution of the national population by race/population group in the 2011 Census: Black African 79.2\%; Coloured 8.9\%; Indian/Asian 2.5\%; White 8.9\% and Other 0.5\% (Statistics South Africa 2012, 17). What we see from the above is how inequalities in educational performance, co-occurring with both race and language, appear to create conditions for, or to exacerbate, structural violence.

In multilingual Senegal, where the 2015 results were described as a disaster, language appears to be laying the foundations for the future reproduction of class-based social inequality. In several (international) private, premium-fee charging schools, we see how investments in the French language seem to be creating the conditions for success in the baccalaureat (or end of high school) examinations. Mastery of the French language is a selling point in the linguistic landscape of some of these schools, as the publicity material on the school in Figure 1 shows.

What is striking about the publicity material in Figure 1 is the suggestion that the school's baccalaureate performance profile (consistent pass rate of 93\%) is to be seen against the backdrop of the emphasis on initiatives that ensure mastery of the French language, and in light of a majority of the teachers holding qualifications from France. The reality, therefore, is that with the current examination language policy and practice, children from low socio-economic backgrounds in under-resourced public schools have poorer prospects of success because comparable investments in French cannot be made nor can teachers with qualifications from France be recruited. 


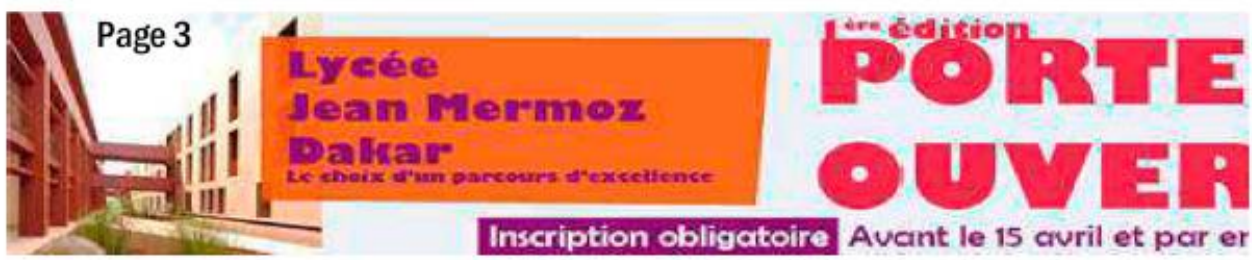

\section{Focus sur le Lycée Jean Mermoz Dakar}

Le Lycée Jean Mermoz propose une scolarité complète du CP à la terminale ; les trois filières d'enseignement général y sont représentées ainsi que la filière STMG (sciences et technologies du management et de la gestion).

L'identité du lycée est construite autour de l'excellence, les enseignants sont en très grande majorité titulaires de l'Education Nationale Française. L'établissement affiche un taux de réussite de 93,3\% aux examens du baccalauréat sur les quatre dernières années.

Les actions sont centrées sur la maîtrise de la langue française, le développement des langues vivantes (l'offre est enrichie en anglais dès le primaire et se renforce dans le secondaire à travers un dispositif bilangues en 6ème/5ème et une section européenne en classe 4ème), l'ouverture sur le Sénégal, la construction du projet personnel de l'élève.

Figure 1. French and performance inequality in Senegal. Source: http://www.ambafrance-sn.org/no7-Avrit-2015.

In multilingual Nigeria, there is reason to suspect that the use of English at the end of high school examinations is not helping to reduce the educational achievement gap between the country's southern and northern halves. Across both halves, there are different pedigrees of literacy exposure to English and different intensities of use of English in daily life. Compared to many parts of the northern half where Hausa is a more or less established lingua franca, different varieties of English play a greater role in the daily lives of individuals in the southern half, most especially in the regions referred to as South-East and South-South. In Figure 2, we plot the 2014 West African Senior School Certificate Examination results per state in Nigeria onto a geo-political map of the country. The numbers on the map reflect the performance of individual states comprising each of the geo-political regions in the 2014 examination.

In Figure 2, we see that 13 of the better performing 14 states were in the south (with the SouthSouth and South-East zones accounting for 10 of these), and 13 of the low performing 14 states were in the northern parts of the country. This picture is consistent with a recurring geographical patterning in students' performance. 


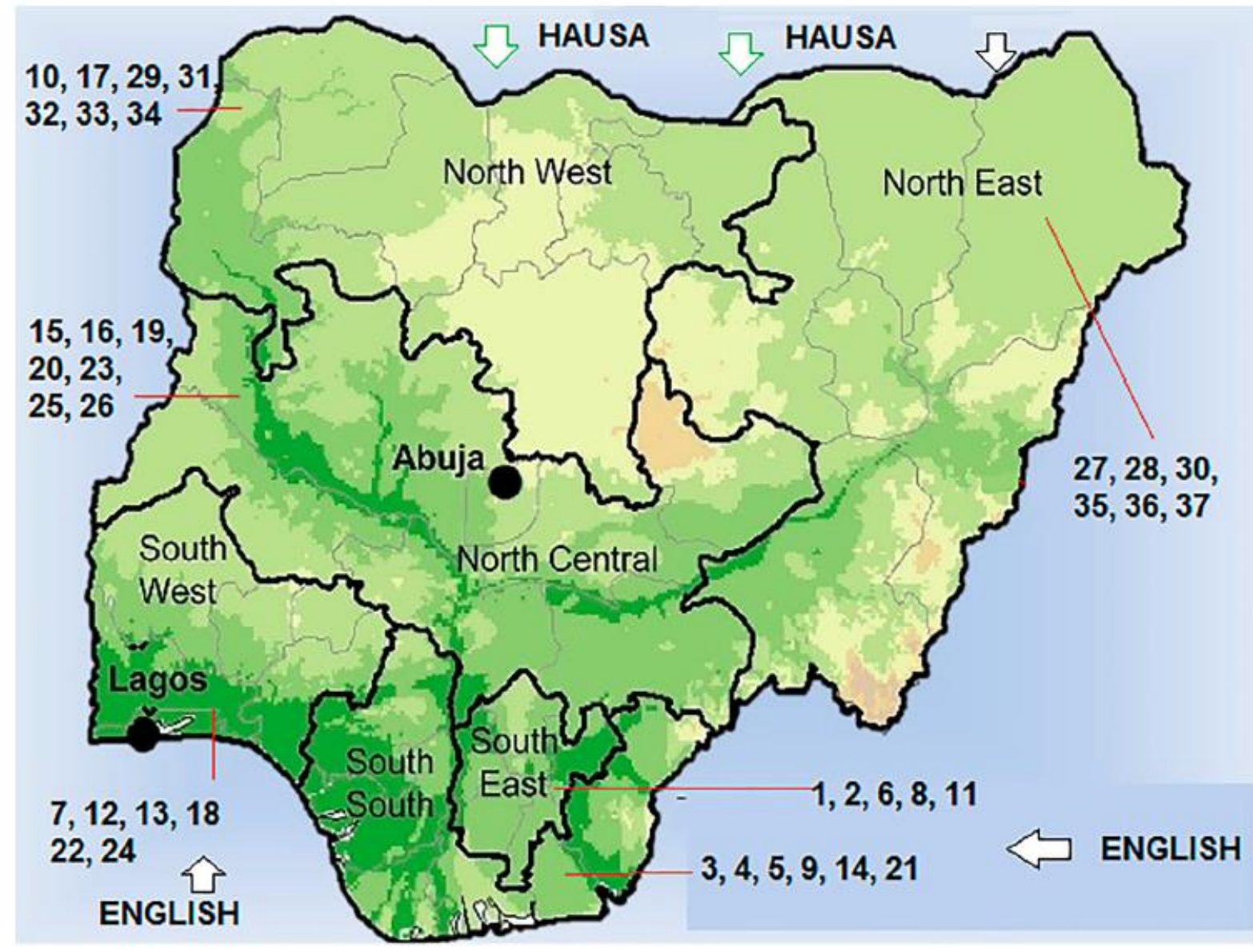

Figure 2. Geographic profile of performance in West African Senior School Certificate Examinations 2014 in Nigeria.

What is suggested by the penal accountancy and structural violence frames as well as by the exemplifications in the form of differential achievement patterns, is just how levels of proficiency and academic literacy in the languages employed in administering examinations can easily be entangled with questions of social justice. The language of examinations can engender consequences that are profoundly social, in part because socially conditioned patterns of access to these languages create an uneven playing field. Such a setting makes it so much harder for the agency of disadvantaged students, teachers or schools to count. Given the foregoing, the question arises as to how society might engage with examinations and the place of language in them - in order to reduce forms of performance inequality.

\section{Multilingual examinations: theoretical foundations as well as the contents and discontents of a response}

Educational theories of measurement and testing provide a broader philosophical context for thinking through how language can become less of a tool of penal accountancy in examinations. In the educational measurement literature, the notion of consequential validity or social consequences validity has become established. One acceptation of the notion of consequential validity derives from the need for social sensitivity in the manner tests are conceptualized, as a bulwark against unintended consequences especially for power minorities in diverse or 
multicultural environments (Frey 2015; Slomp, Corrigan, and Sugimoto 2014). Frey (2015) argues that the consequential validity of a test does not affect construct validity or the particular trait being measured, and that it can be established through a consideration of how the test is socially consumed. Writing on bias in the context of tests that are employed to place individuals in study tracks, Frey $(2015,25)$ poses the following question which illustrates the import of consequential validity: 'If members of different races, ethnicities, or genders are more or less likely to receive different placements, over time does that have a positive or negative effect on society?' A related notion is that of differential validity. An examination that displays differential validity is one that is more or less 'accurate and fair for some groups, but not for others' (Frey 2015, 23).

Slomp, Corrigan, and Sugimoto (2014) illustrate how a social dimension reframes attention, or the nature of evidence, at different stages of reflection about a test. Thus, rather than a putatively unbiased construct definition such as 'Has the construct been specifically defined?' a consequential validity perspective asks: 'How well is the construct understood? How stable is this construct across social, cultural or racial contexts?' Similarly, from the standpoint of the design process, whereas construct validity asks whether 'the assessment [is] designed to ensure that the construct is measured effectively,' a consequential validity lens asks whether the design contributes to 'potentially adverse impacts, impact on populations demonstrated to be at risk' (Slomp, Corrigan, and Sugimoto 2014, 281).

The broader context of consequential validity suitably frames translanguaging as a response to the nexus of language, examination performance and social inequality depicted in preceding sections. Drawing on Lee (2018), Baker (2011) and García (2009), we take a view of translanguaging as the enhancement of communicative potential through a process of making meaning across language boundaries. Translanguaging challenges the putative canon of meaning-making through impermeably delineated sets of resources. While the trans-prefix simultaneously captures the shuttling across as well as the undoing of socially constructed language boundaries, the verbal noun suffix -ing highlights the agentive, process or creative nature of hybrid language use.

We propose that examination questions be presented bi/multilingually, using a co-languaging format, even if as a first step students only have to write in one language. A co-languaging format allows for comparing and contrasting the ways concepts are expressed (van der Walt 2013, 149). While paradoxically relying on a notion of languages as bounded sets of resources as its point of departure, translanguaging based on a co-languaging arrangement arguably enables students to make, verify or identify with meaning across languages in multiple ways and for multiple reasons, including benefits to which they may otherwise not have access as a result of monolingual arrangements.

Indeed, the view by Lee $(2018,8)$ that translanguaging 'confronts the inequitable discursive economies that afford disproportionate amounts of discursive capital' to privileged groups is especially relevant in contexts such as are dealt with in this article: inequality of access to privileged languages in formal education, inequality of representation of languages in 
education, language-correlated inequality in performance in high stakes examinations, inequality of access to opportunities that are contingent on performance in such examinations. García and Wei $(2014,134)$ have claimed that 'translanguaging in assessment has the potential to truly assess what students know how to do both conceptually and linguistically.'

South Africa's matric offers an example of one type of arrangement that allows for translanguaging in examinations. As a consequence of the apartheid legacy of official bilingualism in English and Afrikaans, matric in content subjects is administered only in these languages, to the exclusion of the nine other (African) languages declared official since the end of apartheid. Both English and Afrikaans versions of the question paper are collected in the same booklet in a co-languaging format. Although students are expected to focus on the question paper in the language in which they had registered to write the examination, they are afforded the opportunity to engage in trans-languaging by the co-languaging format. Let us consider a number of datasets from the Western Cape province of South Africa that enable us to determine whether this bilingual arrangement is leveraged, by whom and to what ends. ${ }^{2}$

In a computer-based simulation of the matric in which 12 undergraduate students were recruited, the task was for each student to individually answer the multiple choice question (MCQ) section of the November 2011 matric in a content subject of their choice. Participants were informed that English and Afrikaans versions of the question paper had been placed on computer desktops but they were to answer the version in the language in which they had written the examination years back; they were also informed that a computer program would record all their screen activities, and that during a follow-up interview the recording would be played back to them to aid recall.

Four of the participants reported having the Kaaps version of Afrikaans as home language and indicated they would be writing the simulation in Afrikaans; another four reported English as home language and elected to write in this language; four reported isiXhosa or isiZulu as home language(s), and indicated they would be writing the English version of the simulation. Although not instructed to read across languages, participants who could engage in translanguaging did, presumably re-enacting their own examination hall practices of years back. See Table 1.

Table 1 shows that all four of the Afrikaans home language (actually Kaaps-speaking) participants writing in Afrikaans also consulted the English; two English-home language participants consulted the Afrikaans version; and of the four isiXhosa/isiZulu-speaking participants answering in English, only one knew and consulted Afrikaans. 
Table 1. Overview of language consultation patterns in simulation of matriculation examination.

\begin{tabular}{|c|c|c|}
\hline Participants & Consulting Afrikaans version of examination & Consulting English version of examination \\
\hline \multicolumn{3}{|c|}{ Home language Afrikaans } \\
\hline \multicolumn{3}{|c|}{$\# 1$} \\
\hline \multicolumn{3}{|l|}{$\# 2$} \\
\hline \multicolumn{3}{|l|}{ \#3 } \\
\hline \multicolumn{3}{|c|}{ \#4 } \\
\hline \multicolumn{3}{|c|}{ Home language English } \\
\hline$\# 1$ & $\times$ & $\sqrt{ }$ \\
\hline \#2 & $\times$ & $\sqrt{ }$ \\
\hline \#3 & $\sqrt{ }$ & $\sqrt{ }$ \\
\hline$\# 4$ & $\sqrt{ }$ & $\sqrt{ }$ \\
\hline \multicolumn{3}{|c|}{ Home language isiXhosa/isizulu } \\
\hline$\# 1$ & $\times$ & $\sqrt{ }$ \\
\hline \#2 & $\times$ & $\sqrt{ }$ \\
\hline \#3 & $\times$ & $\sqrt{ }$ \\
\hline$\# 4$ & $\sqrt{ }$ & $\sqrt{ }$ \\
\hline
\end{tabular}

A sense of how translanguaging prevents language from being an obstacle in tests can be seen in Table 2 which presents data on a Kaaps-speaking participant answering in Afrikaans.

For the seven questions shown in Table 2, the student processed five of them across both languages, getting only one question wrong. The latter was a question on an abbreviation, which happened to be the same in both languages. For two other questions, this participant did not bother consulting the English as the Afrikaans was readily understood. Consistently, the rationales given for consulting English clearly show that these Kaaps-speakers' level of familiarity with standard Afrikaans was an impediment. 3 For this and other participants who had elected to write the simulation in Afrikaans, English was at certain points truly a lifeline. The communicative potential of the test was clearly enhanced by an arrangement that enabled the participants to read across languages. Interestingly, shuttling between English and Afrikaans did not mean participants unduly spent more time. For instance, on no question in Table 2 did the participant spend more than 1 minute, 30 seconds, which is the maximum time recommended by the examining body for each question in this section of the examination.

The pattern of consultation and the nature of the benefits seen in Tables 1 and 2 respectively are consistent with the data in an earlier study (Antia 2017b). In that study, 119 undergraduate students, divided into the same 3 demographic groups, recalled their language behaviour at the time they wrote matric as well as benefits associated with such language behaviour. See Table 3 .

Table 3 shows, for instance, that $75 \%$ of the largely Kaaps-speaking respondents who had registered to write the matric in Afrikaans recall consulting the English version in the examination hall, with $69 \%$ of them reporting benefit from such translanguaging. The figure for English home language respondents consulting the Afrikaans version was $41 \%$ and all of these respondents reported benefits. 
Table 2. Dynamics and benefits of translanguaging in data from a Kaaps-speaking participant.

\begin{tabular}{|c|c|c|c|c|c|}
\hline \multirow[b]{2}{*}{ Question } & \multicolumn{3}{|c|}{$\begin{array}{c}\text { Languages consulted (according to } \\
\text { sequence) and time spent per language } \\
\text { consultation }\end{array}$} & \multirow{2}{*}{$\begin{array}{l}\text { Answer and } \\
\text { correctness }\end{array}$} & \multirow[b]{2}{*}{ Motivation } \\
\hline & Afrikaans & English & Afrikaans & & \\
\hline 1 & $\begin{array}{l}40 \text { seconds (sec) } 70 \\
\text { milliseconds (mill) }\end{array}$ & - & - & $C \sqrt{ }$ & Not a problem. I did not need to consult English. \\
\hline 2 & $43 \mathrm{sec} 90$ mill & $\begin{array}{l}60 \mathrm{sec} \\
20 \mathrm{mill}\end{array}$ & - & $A \sqrt{ }$ & $\begin{array}{l}\text { The word beleidsraamwerk wasn't clear to me. The } \\
\text { English term policy framework was easier to } \\
\text { understand. }\end{array}$ \\
\hline 3 & $17 \mathrm{sec} 80$ mill & $\begin{array}{l}11 \mathrm{sec} \\
70 \mathrm{mill}\end{array}$ & - & $D \sqrt{ }$ & $\begin{array}{l}\text { I knew that the sho't left campaign was about } \\
\text { promoting tourism within South Africa but I } \\
\text { couldn't decide between the options C (Kultuur- } \\
\text { en-erfenisontwikkeling) and D (Binnelandse } \\
\text { Toerismegroei). When going to the English text, the } \\
\text { answer became clear as soon as I saw the word } \\
\text { domestic. }\end{array}$ \\
\hline 4 & $8 \mathrm{sec} 40 \mathrm{mill}$ & - & - & $B \sqrt{ }$ & Understood easily. \\
\hline 5 & $1 \mathrm{~min} 6 \mathrm{sec} 20 \mathrm{mill}$ & $\begin{array}{l}13 \mathrm{sec} \\
20 \mathrm{mill}\end{array}$ & - & $\mathrm{Cx}$ & Not useful [as] abbreviations were the same. \\
\hline 6 & $1 \mathrm{~min} 14 \mathrm{sec} 50 \mathrm{mill}$ & $8 \mathrm{sec}$ & $\begin{array}{l}3 \mathrm{sec} \\
6 \mathrm{mill}\end{array}$ & $C \sqrt{ }$ & $\begin{array}{l}\text { By looking at the options given in Afrikaans, I } \\
\text { couldn't really distinguish between the options } \\
\text { given. By looking at the English text, the answer } \\
\text { was clear and the options were clear as well. }\end{array}$ \\
\hline 7 & $1 \mathrm{~min} 4 \mathrm{sec} 80 \mathrm{mill}$ & $16 \mathrm{sec}$ & - & $C \sqrt{ }$ & $\begin{array}{l}\text { I could not make sense of the options when I looked } \\
\text { at the Afrikaans version, yet I knew exactly what } \\
\text { the answer was in English. The connection } \\
\text { between the English question and answer was } \\
\text { clearer. }\end{array}$ \\
\hline
\end{tabular}

Table 3. Reported patterns and benefits of consulting alternate language matric.

\begin{tabular}{|c|c|c|c|c|}
\hline \multirow[b]{2}{*}{ Language profiles of respondents } & \multicolumn{2}{|c|}{$\begin{array}{c}\text { Respondents' language behaviour } \\
\ldots\end{array}$} & \multicolumn{2}{|c|}{ Benefits } \\
\hline & $\begin{array}{l}\text { Consulted } \\
\text { altemate L (\%) }\end{array}$ & $\begin{array}{l}\text { Never consulted } \\
\text { alternate } L(\%)\end{array}$ & $\begin{array}{l}\text { Benefits reported } \\
\text { from consultation } \\
(\%)\end{array}$ & $\begin{array}{l}\text { No/hardly any benefit } \\
\text { reported from } \\
\text { consultation }(\%)\end{array}$ \\
\hline $\begin{array}{l}\text { (1) HL speakers of LL (typically isiXhosa) } \\
\text { other than English and Afrikaans } \\
\text { writing matric in English ( } n=43 \text { ) }\end{array}$ & 19 & 81 & 14 & 86 \\
\hline $\begin{array}{l}\text { (2) HL speakers of Afrikaans writing } \\
\text { matric in Afrikaans }(n=40)\end{array}$ & 75 & 25 & 69 & 31 \\
\hline $\begin{array}{l}\text { (3) HL speakers of English writing the } \\
\text { matric in English }(n=36)\end{array}$ & 41 & 59 & 42 & 58 \\
\hline
\end{tabular}

Key: $\mathrm{L}=$ language; $\mathrm{LL}=$ Languages; $\mathrm{L} 1$ = home language.

It is perhaps worth noting that Afrikaans (contrary to the impression created by the frequent recourse to English) was not always an impediment to understanding questions. On the contrary, in a study in which the terminology of English and Afrikaans life sciences matric examinations (for the years 2010-2013) was compared, there were twice as many terms in Afrikaans that were reported by undergraduate respondents as easier to understand than the corresponding English terms (Antia 2017b). In part, this was because Afrikaans sometimes used a less scientific register compared to English (e.g. 'geboorte' for English 
'parturition') or generally because the language is reported (e.g. by Donaldson 1993, 435) to use compounding more than English.

While Tables 1-3 largely convey the sense of contentment of home language users of either or (especially) both of English and Afrikaans, they also allow us to infer the discontentment of black African students who are denied the affordances of their peers. Many of these black students do not know Afrikaans; do not have English as home language; and (in the Western Cape) would have been taught by teachers using translanguaging (English-isiXhosa) pedagogy. As seen above, these students engage the least in examination hall translanguaging. Clearly, the current language arrangement leads to an examination that displays differential validity. For many black students, the examination may just be akin to linguistic penal accountancy. With the non-inclusion of black African languages as languages of matric, insight and resources relevant to reconfiguring relations of power in education and in society are possibly withheld.

Incidentally, the government has recently scrapped a language compensation mechanism (Leanne 2014) through which $5 \%$ of a student's original examination score was added where the student was not writing the matric in their home language and was therefore believed to be disadvantaged (Taylor 2014). According to a government spokesperson (cited by Leanne 2014), government attention to the English language competency of learners has yielded such benefits that this interim measure can now be discontinued without harm to the concerned group of students. Although the basis for this optimistic assessment remains to be seen, the $5 \%$ language compensation, in any case, reflected a politics of (token) affirmation when what was required was arguably a politics of (fundamental) transformation, to use terms employed by Stroud (2001) in a different context. It may be asked why the majority of students (black African) should be accommodated by a minority as though the majority were a small, newly arrived immigrant group.

In sum, the non-use of isiXhosa along with English and Afrikaans as a co-examination language in South Africa's Western Cape Province arguably has the same consequences as the non-use of Wolof along with French in parts of Senegal, Amharic along with English in parts of Ethiopia, Creole with French and English in parts of Mauritius, and so on. South Africa's bilingual matric paints a picture of contents and discontents in relation to the current arrangements for translanguaging in examinations.

\section{Conclusion}

This article has attempted to argue that a monolingual exoglossic language regime for examinations in multilingual sub-Saharan Africa is an aberration, with consequences that engender and perpetuate social inequalities, and work against the redistribution of educationally contingent social and political capital. The aberration was evident in the four paradoxes described. The consequences were seen in the deplored quality of passes, in the social structuring of results, as well as in the social uses or consumption of these results - that is, the performance-based access to opportunity in higher education and on the labour market. 
To address the penal balance-sheet which examination language policies and practices in the region produce - a balance-sheet that reinforces structural violence - it is clearly important to evolve a model of examination language policy and practice that is attuned to the sociolinguistic realities of students. While testing exclusively in major national languages, thus replacing exoglossic languages, may well be an option, it is not the one favoured here.

It hardly bears stating that, in multilingual environments, individuals seldom acquire knowledge in only one language. It often is the case that individuals in such multilingual contexts obtain curriculum-relevant knowledge across languages, using a relevant dominant constellation of languages. Rather than the substitution of an endoglossic language for an exoglossic one, the plea here is for multilingual arrangements that make translanguaging possible in examinations. García (2014, 157) argues that just as 'scholars and practitioners work on implementing translanguaging pedagogies and measuring their effects, others need to develop bilingual [also multilingual] assessment that would allow students to use their entire linguistic repertoires to show what they know.' The potentials of a translanguaging arrangement were illustrated with the South African matric examination in the Western Cape Province.

There is no doubt that altering current linguistic arrangements for the end of high school examinations in sub-Saharan Africa is a monumental challenge, considering vested interests in the status quo, as amply documented by a number of scholars. For example, Alidou (2002), BrockUtne (2008), Djité (2008), Qorro (2009) and others have analysed the volume of book publishing business associated with the use of erstwhile colonial languages, the size of the foreign examinations market on the continent, the market for language consultants, as well as conditions for donor aid and for transacting other kinds of national bilateral business. As a result of these interests and pressures, policy intervention to change the status quo would require a muchheightened sense of enlightened national interest among governments in the region than seems to currently be the case.

Some bases for rethinking examination language policies could include the prospects of:

- greater return on investment for national governments in terms of their per capita expenditure in secondary education, thanks to possibly higher performance rates;

- a reduction in the army of disenchanted high school graduates who come up short in the judgment and classification of examination bodies, and thus have limited market solvency;

- a variety of washback effects, including the emergence of a local language book publishing industry for secondary education, especially in the examination revision sub-sector; the emergence and professionalization of an African language workforce; accelerating the development of African languages; and obtaining legitimacy for the still surreptitious practice of pedagogical translanguaging.

It would be disingenuous to seek to hinge the non-use of African languages on concerns of terminology. There now exists a large body of evidence that gives the lie to claims that terminologies are not available or cannot be developed in African languages. A review of some relevant initiatives 
can be found in Antia (2000), including Cheik Anta Diop's work on Einstein's relativity theory in Wolof; the dictionaries and other resources in Kiswahili produced by the Tanzanian National Swahili Council on a range of subject fields; the metalinguistic terminologies in several Nigerian languages; the Scientific and Technological Terminology in Amharic project of the Ethiopian Science and Technology Commission and the Academy of Ethiopian Languages; specialized lexis projects in languages of countries in so-called Francophone Africa; among others.

\section{Notes}

1. Arabic would be a sixth language at the continental level, rather than specifically in subSaharan Africa.

2. In this province, the official languages are English, isiXhosa and Afrikaans. The Kaaps variety of the latter is spoken in coloured communities and it has a larger speaker base than the standard variety. Kaaps includes many English loanwords.

3. These datasets were obtained at the University of the Western Cape where respondents were more at home with the Kaaps variety of Afrikaans than with the formal variety. The patterns seen might have been different at another institution with respondents who are more at home with the standard variety.

\section{Disclosure statement}

No potential conflict of interest was reported by the author.

\section{Notes on contributor}

Bassey E. Antia is Professor in the Department of Linguistics at the University of the Western Cape, South Africa. Across multilingualism and terminology (two areas of his research emphasis), his work problematizes and seeks to respond to the marginality experienced by specific groups in education. He has previously authored Terminology and Language Planning, and edited Indeterminacy in Terminology and LSP, both from Benjamins. Recent journal articles have appeared in Language Policy, International Journal of the Socioloigy of Language, and Terminology. 


\section{References}

Adedeji, Segun Olugbenga, and Olanrewaju Olaniyan. 2011. Improving the Conditions of Teachers and Teaching in Rural Schools Across African Countries. Addis Ababa: UNESCO International Institute for Capacity Building in Africa.

Alidou, Ousseina. 2002. "French Colonial Education and its Postcolonial Legacy in Francophone Africa." In Visionen für das

Bildungssystem in Afrika [Education Systems in Africa - Visions and Prospects], edited by L. Imunde, 51-64. Rehburg-Loccum: Loccum Akademie.

Alidou, Hassana, and Ingrid Jung. 2002. "Education Language Policies." In Francophone Africa: What Have We Learned from Field Experience? In Language Policy: Lessons from Global Models, edited by Steven Baker, 61-73. Monterey: Monterey Institute of International Studies.

Antia, Bassey E. 1996. "Situation audiovisuelle dans un pays multilingue: Le Nigéria." In Les transferts linguistiques dans les médias audiovisuels", edited by Yves Gambier, 61-72. Villeneuve d'Asq (Nord): Presses universitaires du Septentrion. Antia, Bassey E. 2000. Terminology and Language Planning: An Alternative Framework of Discourse and Practice. Amsterdam: John Benjamins.

Antia, Bassey E. 2017a. "Shh, Hushed Multilingualism! Accounting for the Discreet Genre of Translanguaged Siding in Lecture Halls at a South African University." International Journal of the Sociology of Language 243: 183-198. doi:10. 1515/ijsl-2016-0052.

Antia, Bassey E. 2017b. "Multilingual Terminology and Cognition in Assessment." In Multilingualism and Intercultural Communication: A South African Perspective, edited by Russell Kaschula, Pamela Maseko, and H. Ekkehard Wolff, 92-111. Johannesburg: Wits University Press.

Antia, Bassey E., and Charlyn Dyers. 2016. "Epistemological Access Through Lecture Materials in Multiple Modes and Language Varieties: The Role of Ideologies and Multilingual Literacy Practices in Student Evaluations of Such Materials at a South African University." Language Policy 15 (4): 525-545. doi:10.1007/s10993-015-9389-4.

Antia, Bassey E., and Charlyn Dyers. 2017. "Affirming the Biliteracy of University Students: Current Research on the Provision of Multilingual Lecture Resources at the University of the Western Cape.” In Academic Biliteracies - Translanguaging and Multilingual Repertoires in Higher Education Settings, edited by David M. Palfreyman and Christa van der Walt, 113-141. Bristol: Multilingual Matters.

Baker, Colin. 2011. Foundations of Bilingual Education and Bilingualism. 5th ed. Bristol: Multilingual Matters.

Bamgbose, Ayo. 2000. Language and Exclusion. The Consequences of Language Policies in Africa. Münster: LIT.

Bamgbose, Ayo. 2004. "Language of Instruction Policy and Practice in Africa." Accompanying text to UNESCO's map of

African community languages and their use in education. Accessed 15 May 2016. www.unesco.org/education/languages_2004/languageinstruction_africa.pdf.

Banda, Felix. 2010. "Defying Monolingual Education: Alternative Bilingual Discourse Practices in Selected Coloured Schools in Cape Town.” Journal of Multilingual and Multicultural Development 31 (3): 221-235. 
Banda, Felix. 2016. "Towards a Democratisation of New Media Spaces in Multilingual/Multicultural Africa: A Heteroglossic Account of Multilocal and Multivoiced Counter-hegemonic Discourses in Zambian Online News Media." Stellenbosch Papers in Linguistics Plus 49: 105127.

Bayat, Amiena, Wynand Louw, and Ravinda Rena. 2014. "The Impact of Socio-economic Factors on the Performance of Selected High School Learners in the Western Cape Province, South Africa." Journal of Human Ecology 45(3): 183-196.

Botswana Examinations Council. 2015. "Press Release: 2015 Botswana General Certificate for Secondary Education (BGCSE) Results Released.” Accessed 14 April 2016. http://www.bec.co.bw/press-release-2015-botswana-general-certificate-for-secondaryeducation-bgcse-results-released.

Brock-Utne, Birgit. 2008. "Language and Democracy in Africa." In Equality in Education. Comparative and International Perspectives, edited by Donald B. Holsinger and Jacob James, 172-189. Hong Kong: Comparative Education Research Centre, The University of Hong Kong.

Chimbutane, Feliciano. 2012. "Multilingualism in Education in Post-colonial Contexts: A Special Focus on Sub-Saharan Africa." In The Routledge Handbook of Multilingualism, edited by Marilyn Martin-Jones, Adrian Blackledge, and Angela Creese, 167-183. Abingdon: Routledge.

Daily Nation. 2016. "Three-quarters of KCSE Mean Grade A Went to Boys." Accessed 11 May 2016. http://www.nation.co. Ke/news/Drop-in-candidates-who-scored-mean-A//1056/3102426/-/elrnc6/-/index.html.

Dia, Pape Mor, and Ahamdou Mbaye. 2015. "Résultats catastrophiques au Bac 2015: A qui la faute?" Accessed 10 March 2016. http://www.senenews.com/2015/08/03/reportage-senenewsresultats-catastrophiques-au-bac-2015-a-qui-la-faute_136089.html.

Djité, Paulin G. 1990. "The Place of African Languages in the Revival of the Francophonie Movement." International Journal of Sociology of Language 86 (1): 87-102.

Djité, Paulin G. 2008. The Sociolinguistics of Development in Africa. Clevedon: Multilingual Matters. Donaldson, Bruce C. 1993. A Grammar of Afrikaans. Berlin: Mouton de Gruyter.

Doozie, Pius. 2015. "WASSCE 2015, Who is to Blame for the Poor Performance, Teachers or Students???” $\quad$ Accessed $10 \quad$ March 2016. https://www.modernghana.com/news/636146/1/wassce-2015-who-is-to-blame-for-thepoor-performan.html.

Equal Education. 2015. "Press Statement: Upcoming 2015 Matric Results Require Careful Scrutiny!" Accessed 15 May 2016. http://old.equaleducation.org.za/article/2016-01-03-upcoming2015-matric-results-require-careful-scrutiny.

Fakeye, David O. 2014. "English Language Proficiency as a Predictor of Academic Achievement among EFL Students in Nigeria.” Journal of Education and Practice 5 (9): 38-41.

Fardon, Richard, and Graham Furniss. 1994. "Introduction. Frontiers and Boundaries - African Languages as Political Environment.” In African Languages, Development and the State, edited by Richard Fardon and Graham Furniss, 2-29. London: Routledge.

Ferguson, Gibson. 2003. "Classroom Code-switching in Post-colonial Contexts Functions, Attitudes and Policies." In African and Applied Linguistics. AILA Volume Review Volume 16, edited by Sinfree Makoni and Ulrike H. Meinhof, 38-51. Amsterdam: John Benjamins. 
Fleisch, Brahm. 2008. Primary Education in Crisis: Why South African Schoolchildren Underachieve in Reading and Mathematics. Cape Town: Juta and company.

Foucault, Michel. 1991. Discipline and Punish. The Birth of the Prison. 2nd ed. New York: Vintage Books. Frey, Bruce B. 2015. 100 Questions (and Answers) about Tests and Measurement. Los Angeles: Sage.

Gadelii, Karl E. 2004. "Annotated Statistics on Linguistic Policies and Practices in Africa." Accessed 14 April 2016. http://www.sprak.gu.se/digitalAssets/1310/1310354_annotatedstatistics.pdf.

Galtung, Johan. 1969. "Violence, Peace and Peace Research.” Journal of Peace Research, 6 (3): 167-191. García, Ofelia. 2009. "Education, Multilingualism and Translanguaging in the 21st Century." In Multilingual Education for Social Justice: Globalising the Local, edited by A. Mohanty, M. Panda, R. Phillipson, and T. Skutnabb-Kangas, 128-145. New Delhi: Orient Blackswan.

García, Ofelia. 2014. "Becoming Bilingual and Biliterate. Sociolinguistic and Socio-political Considerations." In Handbook of Language and Literacy Development and Disorders, edited by C. A. Stone, E. R. Silliman, B. J. Ehren, and G. P. Wallach, 145-160. New York: The Guildford Press.

García, Ofelia, and Li Wei. 2014. Translanguaging: Language, Bilingualism and Education. Basingstoke: Palgrave Macmillan. Githiora, Chege. 2016. "Sheng: The Expanding Domains of an Urban Youth Vernacular.” Journal of African Cultural Studies. doi:10.1080/13696815.2015.1117962.

Glewwe, Paul W., Eric A. Hanushek, Sarah D. Humpage, and Renato Ravina. 2011. "School Resources and Educational Outcomes in Developing Countries: A Review of the Literature from 1990 to 2010." NBER Working Paper No. 17554. Accessed 5 April 2017. http://www.nber.org/papers/w17554.

Glewwe, Paul, and Michael Kremer. 2006. "Schools, Teachers, and Education Outcomes in Developing Countries." In Handbook of the Economics of Education. Volume 2, edited by E. Hanushek and F. Welch, 945-1017. Amsterdam: North-Holland.

Glewwe, Paul, Michael Kremer, and Sylvie Moulin. 2009. "Many Children Left Behind? Textbooks and Test Scores in Kenya." American Economic Journal: Applied Economics 1 (1): 112-135.

Heugh, Kathleen. 2011a. "Theory and Practice - Language Education Models in Africa: Research, Design, Decision-making and Outcomes.” In Optimising Learning, Education and Publishing in Africa: The Language Factor. A Review and Analysis of Theory and Practice in Mothertongue and Bilingual Education in Sub-Saharan Africa, edited by Adama Ouane and Christine Glanz, 105-156. Hamburg: UNESCO Institute for Lifelong Learning/Association for the Development of Education in Africa (ADEA).

Heugh, Kathleen. 2011b. "Cost Implications of the Provision of Mother-tongue and Strong Bilingual Models of Education in Africa." In Optimising Learning, Education and Publishing in Africa: The Language Factor. A Review and Analysis of Theory and Practice in Mothertongue and Bilingual Education in Sub-Saharan Africa, edited by Adama Ouane and Christine Glanz, 255-289. Hamburg: UNESCO Institute for Lifelong Learning/Association for the Development of Education in Africa (ADEA).

Heyneman, Stephen P., Joseph P. Farrell, and Manuel A. Sepulveda-Stuardo. 1981. "Textbooks and Achievement in Developing Countries: What We Know." Journal of Curriculum Studies 13 (3): 227-246. 
Johannes, Mekonnen Alemu Gebre. 2009. "Implications of the Use of Mother Tongues Versus English as Languages of Instruction for Academic Achievement in Ethiopia." In Languages and Education in Africa: A Comparative and Transdisciplinary Analysis, edited by B. Brock-Utne and I. Skattum, 189-199. Oxford: Symposium Books.

Kellaghan, Thomas, and Vincent Greaney. 1992. Using Examinations to Improve Education: A Study in Fourteen African Countries. World Bank Technical Paper Number 165. Africa Technical Department Series. Washington, DC: World Bank.

Kellaghan, Thomas, and Vincent Greaney. 2003. Monitoring Performance: Assessment and Examinations in Africa. Paris: Association for the Development of Education in Africa (ADEA).

Leanne, Jansen. 2014. "Extra Marks for African-language Pupils Have Been Scrapped for Matric." Accessed 17 December $2016 . \quad$ https://www.pressreader.com/south-africa/capetimes/20140714/281517929233346.

Leclerc, Jacques. 2015. Sénégal. Accessed $15 \quad$ May 2016. http://www.axl.cefan.ulaval.ca/afrique/senegal.htm. Lee, Jerry Won. 2018. The Politics of Translingualism. New York: Routledge.

Mc Laughlin, Fiona. 2009. "Senegal's Early Cities and the Making of an Urban Language." In The Languages of Urban Africa, edited by F. Mc Laughlin, 71-85. London: Continuum.

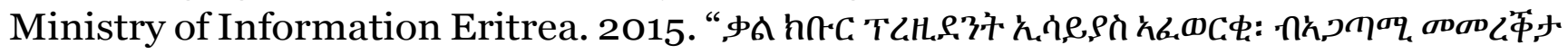

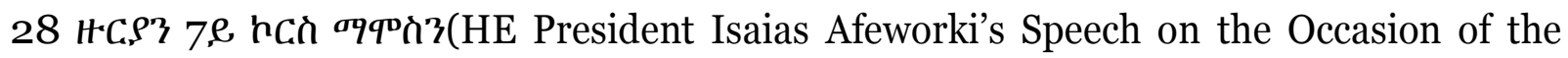
Graduation of Participants of the 28th Round National Service and 7th Course of the Vocational Training in Sawa)." Accessed 28 December 2017. http://50.7.16.234/hadaseritrea/haddas_ertra_12072015.pdf.

Negash, Ghirmai. 1999. A History of Tigrinya Literature in Eritrea: The Oral and the Written, 18901991. Leiden: Research School CNWS.

Nwachukwu, John Owen. 2016. "South-eastern States lead as WASSCE Releases 2015 May/June Results.” Accessed 10 March 2016. http://dailypost.ng/2016/02/05/south-eastern-stateslead-as-wassce-releases-2015-mayjune-results/.

October, Michelle. 2002. "Medium of Instruction and its Effect on Matriculation Examination Results for 2000, in Western Cape Secondary Schools: A Study of Examination Results in Relation to Home Language and Language Medium." MPhil minor diss., University of Cape Town.

Ouane, Adama, and Christine Glanz. 2011. "Executive Summary." In Optimising Learning, Education and Publishing in Africa: The Language Factor. A Review and Analysis of Theory and Practice in Mother-tongue and Bilingual Education in sub-Saharan Africa, edited by Adama Ouane and Christine Glanz, 23-46. Hamburg: UNESCO Institute for Lifelong Learning/Association for the Development of Education in Africa (ADEA).

Qorro, Martha A. S. 2009. "Parents' and Policy Makers' Insistence on Foreign Languages as Media of Education." In Africa: Restricting Access to Quality Education - for Whose Benefit? In Languages and Education in Africa: A Comparative and Transdisciplinary Analysis, edited by B. Brock-Utne and I. Skattum, 57-82. Oxford: Symposium Books.

Slomp, David H., Julie A. Corrigan, and Tamiko Sugimoto. 2014. "A Framework for Using Consequential Validity Evidence in Evaluating Large-scale Writing Assessments: A Canadian Study." Research in the Teaching of English 48 (3): 276-302. 
Statistics South Africa. 2012. "Statistical Release (Revised) Po301.4 Census 2011." Accessed 11 December 2017. https://www.statssa.gov.za/publications/P03014/P030142011.pdf.

Statistics South Africa. 2015. "Statistical Release P0211 Quarterly Labour Force Survey Quarter 2: 2015." Accessed $11 \quad$ December 2017. http://www.statssa.gov.za/publications/Po211/Po2112ndQuarter2015.pdf.

Stroud, Chris. 2001. "African Mother Tongue Programmes and the Politics of Language: Linguistic Citizenship Versus Linguistic Human Rights." Journal of Multilingual and Multicultural Development 22 (4): 339-355.

Tabaro, Cyprien. 2013. "Code-switching in Rwanda: A Case Study of Kigali City Secondary Schools." Southeast Asia: A Multidisciplinary Journal 13: 14-26.

Taylor, Stephen. 2014. "Reviewing the Language Compensation Policy in the National Senior Certificate." Perspectives in Education 32 (1): 124-141.

Traoré, Kardiatou. 2015. "Mali: hécatombe au baccalauréat, résultats catastrophiques!" Accessed 10 March 2016. http:// www.afrik.com/mali-hecatombe-au-baccalaureat-resultatscatastrophiques.

Uganda National Examinations Board. 2016. "Statement on Release of the 2015 UACE Examination Results." Accessed 10 January 2017. http://uneb.ac.ug/downloads/STATEMENT\%20RELEASE\%20UACE\%202015\%20\%20FINAL.docx.pdf.

UNESCO. 2004. "Map of African Community Languages and Their Use in Education." Accessed 15 May 2016. www.unesco.org/education/languages_2004/affichlang_afrique.pdf.

van der Walt, Christa. 2013. Multilingual Higher Education. Beyond English Medium Orientations. Bristol: Multilingual Matters.

van der Westhuizen, Gert J., L. Maseko, K. Van Lelyveld, J. de Beer, L. Kakoma, and U. Ramnarain. 2010. Towards Improving

Learner Performance in the National Senior Certificate Examination - Script Analysis Research Report. Johannesburg: University of Johannesburg.

wa Thiong'o, Ngugi. 1987. Decolonising the Mind. The Politics of Language in African Literature. Harare: Zimbabwe Publishing House.

Yevudey, Elvis. 2013. "The Pedagogic Relevance of Codeswitching in the Classroom: Insights from Ewe-English Codeswitching in Ghana." Ghana Journal of Linguistics 2 (2): 1-22. 